Vol. 44, N. 2 : pp. 165 - 171, June, 2001

ISSN 1516-8913 Printed in Brazil

\title{
Nephrotoxicity of Bence-Jones Proteins : Correlation with Endocytosis by BHK Cells and Intracellular Movement
}

\author{
Ana Lucia Nicastri ${ }^{*}$; Elisa Maines Gomes ${ }^{2}$, Maria José Brandão de Almeida Prado ${ }^{3}$ and \\ Euthymia Brandão de Almeida Prado ${ }^{3}$ \\ ${ }^{1}$ Cellular Biology Department, Federal University of the State of Paraná (UFPR), Curitiba - PR, Brazil; \\ ${ }^{2}$ Immunological Product Development Department, Paraná Technology Institute (TECPAR), Curitiba - PR, Brazil; \\ ${ }^{3}$ Renal Physiopathology Laboratory of the São Paulo University Faculty of Medicine (USP), São Paulo - SP, Brazil
}

\begin{abstract}
The aim of this investigation was to evaluate the endocytosis of two Bence-Jones proteins by renal cells in order to elucidate the interference of their physical and chemical characteristics on nephrotoxicity. Bence-Jones proteins (AK and GL) were purified and isolated from the urine of two patients with multiple myeloma. The isotype of both proteins was characterised as being human monoclonal lambda light chain. The AK protein presented mainly an Ip>7.0, a high content of galactose and a low amount of sialic acid molecules. On the other hand, the GL protein presented a single band with an Ip of 4.3, a higher level of sialic acid and a reduced amount of galactose, in comparison with the AK protein. Baby Hamster Kidney (BHK) cells were maintained in culture in bottles at $37^{\circ} \mathrm{C}$, using DMEM culture media supplemented with $10 \%$ of calf serum with a pH of 7.4. Once the monolayer was observed to be confluent, the BHK cells were incubated with the two proteins, dissolved in a serum-free medium for 1, 5, 15, 30, 60 minutes and 24 hours. Control cells were established omitting the incubation with Bence-Jones proteins, but maintaining all of the other conditions. After, this the cells were washed, trypsinised, centrifuged and fixed in a solution of $4 \%$ paraformaldehyde and $0.5 \%$ glutaraldehyde on a $0.1 \mathrm{M}, \mathrm{pH} 7.4$ phosphate buffer. Cells were processed for immunocytochemical reactions by using protein A coupled with colloidal gold and further silver enhancement. Semi-thin sections of the pellets were obtained and submitted to the cytochemical reactions. Detection of labelling was made by using light microscopy. It was observed that GL protein tended to be directed towards a perinuclear position, whereas the AK protein tended to suffer lysosomal deviation, suggesting that there is a direct contribution of physical and chemical characteristics on intracellular direction taken by Bence-Jones proteins.
\end{abstract}

Key words: Endocytosis, Bence-Jones, Experimental Nephrology

\section{INTRODUCTION}

The pathologies associated with cells which produce immunoglobins or their precursors, B lymphocites and plasmocytes frequently occur together with the production of anomalous proteins, whether in their structure, in the amount produced or in the imbalance in the ratio between fragments, resulting in their systemic circulation, thus favouring their preferential localisation in some tissues (Silver et alii, 1986).

As there is a high blood flow through the kidney, an organ which performs a very delicate filtering process, handling proteins both at glomerular and tubular cell level, mainly by proximal tubular cells, it is not difficult to understand that the kidney undergoes frequent alterations as a result of

Author for correspondence 
the accumulation of these proteins (Cooper at alii, 1984; Sanders et alii, 1988; Cohn et alii, 1984; Prado et alii, 1993).

Multiple myeloma is a disease characterised by the malignant proliferation of a plasmatic cell clone, with the production of whole or partial monoclonal immunoglobins, predominantly of the Kappa type, with greater incidence in people in their fifties (Sinclair et alii, 1986; Kyle, 1983).

There is a direct relationship between kidney failure caused by multiple myeloma and the isoelectric point of the light chains of the immunoglobulins. Studies have shown that patients that secreted light chains which were more cationic, with an $\mathrm{pI}$ of greater than 6.0, were found to have kidney damage, whilst the kidneys of those who excreted light chains with a lower pI level functioned normally (Melcion et alii, 1984).

The relationship between the isoelectric point and nephotoxicity is not linear (Weiss et alii, 1981; Solomon et alii, 1991). Other biochemical characteristics need to be investigated, including the composition of carbohydrates which can alter cellular capture (Jansen et alii, 1991).

The carbohydrate contents of the various classes of immunoglobins were determined by Endo and Kobata (Endo \& Kobata, 1989). Their findings, expressed in $\mathrm{g} / 100 \mathrm{~g}$ of protein, show that $\operatorname{lgG}$ presents fucose (0.2), manose (1.0), galactose (0.5) $\mathrm{N}$-acetylglucosamine (1.0) and sialic acid (0.2). After hydrolysis, the glycopeptides present in the immunoglobulins can be isolated and separated.

Various studies have documented that carbohydrates are not found in the immunoglobulin regions. They have, however, been localised in the variable region of these chains in approximately $15 \%$ of the proteins studied (Sox Jr. \& Hood, 1970). The presence of carbohydrates has been described in the variable region of the heavy chains (Putnam et alii, 1973). In $\operatorname{lgG}$ immunoglobulins, carbohydrate residues are found linked to asparagine residue in the Fc region, at position 297 of the final amino.

Different types of oligosacharides have been found in immunoglobins. Type 1 are of the O-linked type, between $\mathrm{N}$-acetylgalactosamine and serin or treonin. Type 11 and 111 are $\mathrm{N}$-linked between $\mathrm{N}$ acetylglucosamine and aspargine. Among the differences which occur in type 11 and 111 oligosacharides, the former have been observed to present a complex branching structure with a single fucose residue, 3 manose residues, 2 galactose residues and 3 or $4 \mathrm{~N}$-acetylglucosamine residues and may also contain 1 or 2 sialic acid residues. On the other hand, the type 111 unit has only two types of monosacharides, manose and Nacetylglucosamine, having a simple and less branching structure than the previous one, according to Johnson and Clamp (Johnson \& Clamp Jr., 1971).

According to Takasaki et alii (Takasaki et elii, 1982) the use of hydrolysis techniques enabled the elucidation of the oligosacharides found in glycoproteins.

Studies of purified $\lg$ sugar chains taken from the serum of normal patients have revealed characteristics peculiar to this class of immunoglobulins (Harada et alii, 1987). Curiously, only $25 \%$ of the sugar chains linked to aspargine are sialised, as occurs with other seric glycoproteins. The elevated level of microheterogeneity was another characteristic observed, caused by the presence or absence of two galactoses in complex and branching $\mathrm{N}$ acetylglucosamine and also a fucose residue, making possible countless combinations and different sugar chains. Despite this multiplicity, the molar ratio of each dosed oligosacharide in samples obtained from the serum of normal patients is constant. In percentage terms, the molar ratio of neutral, monosialic and disialic oligosacharides is approximately $76: 18: 6$ (Harada et alii, 1987).

Myeloma $\lg$ immunoglobins, products of monoclonal B cells, also contain complex and branching sugar chains. The molar ratio of each liberated oligosacharide is not constant however (Mizuochi et alii, 1982); Endo \& Kobata, 1989). The neutral oligosacharides ranged from $58 \%$ to $90 \%$, whilst the monosialic ones ranged from $9 \%$ to $42 \%$ and the disialic ones ranged from $0 \%$ to $9 \%$.

The majority of myeloma proteins contain two sugar chains linked to asparagine. Even so, some proteins contain larger amounts of carbohydrates. Ohkura et alii (Okhura et alii, 1985) observed that some oligosacharides liberated from Bence-Jones proteins were highly sialised.

The purpose of this study is to examine the physical and chemical characteristics of BenceJones proteins in relation to nephrotoxicity, correlating it to capture by renal cells and also to the intracellular trajectory followed. 


\section{MATERIAL AND METHODS}

\section{Sialic acid dosage}

The methodology described by Svennerholm (Svennerholm, 1957) was used, without prior hydrolysis.

The samples of sialic acid used as controls and the Bence-Jones proteins were diluted in $1 \mathrm{ml}$ of distilled water and mixed with $1 \mathrm{ml}$ of resorcinol reagent $(10 \mathrm{ml}$ of $2 \%$ resorcinol solution, plus $80 \mathrm{ml}$ of concentrated $\mathrm{HCl}$ and $0.25 \mathrm{ml}$ of $0.1 \mathrm{M} \mathrm{CuSO}_{4}$ ). The tubes were sealed with aluminium foil, heated to $100{ }^{\circ} \mathrm{C}$ for 15 minutes and then cooled in water. Following this, $2.5 \mathrm{ml}$ of isoamylic acid were added and the chromophore was extracted at the organic phase, by means of violent shaking. In order to achieve total separation, the tubes were centrifuged at $500 \mathrm{rpm}$ for 2 to 3 minutes. The organic phase was removed and the absorption reading was taken at $580 \mathrm{~nm}$.

In order to evaluate interference caused by neutral hexoses, corrections were made using dichromatic measurements at $450 \mathrm{~nm}$ and $580 \mathrm{~nm}$ on the samples and on the controls following the equation proposed by Spiro (Spiro, 1966).

\section{Neutral sugar dosage}

The samples underwent acid hydrolysis $(4 \mathrm{~N} \mathrm{HCl})$ for 4 hours at $100^{\circ} \mathrm{C}$ in sealed ampoules. The excess $\mathrm{HCl}$ was evaporated at low pressure and the material was suspended again and chromatographed in ionic exchange resins of the "mixed bed" type, with equivalent amounts of Dowex 1-x8 (OH-) and Dowex 5-x8 (H+) (BDH Chemicals Ltd., England) and concentrated until it became dry. The neutral fraction was eluted and concentrated until it became dry. The matter was suspended again in $30 \mathrm{ul}$ of distilled water and subjected to descending chromatography on number 1 Whathman paper using ethyl acetate/isopropane/water solvents $(5: 2: 1 \quad \mathrm{v} / \mathrm{v} / \mathrm{v})$ and $1.25 \mathrm{~N}$ butyric acid/ammonia $(5: 3 \mathrm{v} / \mathrm{v})$ for 10 to 24 hours. The compounds were detected using a silver reagent in an alkaline medium (Trevelyan et alii, 1950). The sugars were quantified using densitometry and compared with known quantities of their respective controls. The hexoamines were dosed but did not pass through the ionic exchange resin.

\section{Determination of the isoelectric point (pI)}

The determination of the $\mathrm{pI}$ was made by means of isoelectric focussing on native samples and on samples from which the sugar residues had been removed, on commercial plates supplied by Pharmacia, with a gradient of 3.0 to 10.0 (Radola, 1980).

\section{Determination of the molecular weight}

The characterisation of the molecular weight of native samples and on samples from which the sugar residues had been removed was carried out using polycrylamide gel in the presence of SDS, using controls as molecular weight labels (Laemmli, 1970).

\section{Capture by renal cells in culture}

The purified light chains taken from the urine of patients suffering from multiple myeloma and previously characterised as to their physical and chemical composition were incubated with commercially obtained BHK lineage kidney cells. The cells were cultivated in bottles, at a temperature of $37^{\circ} \mathrm{C}$, in a DMEM culture medium (Dulbecco's Modified Eagle Medium, Gibco. U.S.A.), enriched with $10 \%$ calf foetus serum (Laborclin) and also containing $100 \mathrm{ug} / \mathrm{ml}$ of penicillin (Fontoura-Wyeth), $100 \mathrm{ug} / \mathrm{ml}$ of streptomycin (CEME) e $5 \mathrm{mg} / \mathrm{ml}$ of amphotericine B (Squibb). 40 ug of light chain were incubated in $1 \mathrm{ml}$ of Dulbecco's culture medium, without calf foetus serum. The incubation times used were 1', 5', 15', 30', 60' and 24 hours. Following this the cells were washed with $0.1 \mathrm{M}$ PBS, trypsinised and placed in conical tubes. After centrifuging, the cells were fixed for 2 hours in a $4 \%$ paraformaldehyde and $0.5 \%$ glutaraldehyde solution in a $7.4 \mathrm{pH}$ phosphate buffer. Following this, they were processed by light microscopy, using hydrophilic resins (LRWhite) which enabled the preservation of the immunogenicity of the proteins detected. The assessment of the endocytosis of the light chains using BHK cells, as well as the accompaniment of the intracellular trajectory were carried out using immunocytochemical techniques with colloidal gold with intensification by means of silver (Nicastri, 1993).

\section{RESULTS}

\section{Characterisation of the Bence-Jones Proteins}

Light chain isotype, molecular weight and isoelectric point. 
The two proteins which were isolated, $\mathrm{AK}$ and GL, were characterised using immunoelectrophoresis as being light monoclonal chains of the lambda isotype. The molecular weight determined by SDS-PAGE was in the region of 28 to $30 \mathrm{Kda}$, these bands being relevant only for light lambda anti-chain antibodies in immunotransferral.

The determination of the load by means of isoelectric focussing showed that the AK protein had bands with an pI varying between 5.9 and 7.5, with a predominance of $\mathrm{pI}>7.0$ and GL protein, a single band with an $\mathrm{pI}$ of 4.3 , remaining clearly distinct in relation to the Ip considered to be critical, with regard to nephrotoxicity, of 5.7 (Dwek et alii, 1993). Taking into account the predominance of bands with an $\mathrm{pI}>7.0$, the AK protein was considered to be neutral, whilst the GL protein was considered to be anionic.

\section{Amino acid composition}

By means of the analysis of amino acids, it was observed that the AK protein, in relation to the GL protein, presented a proportionally greater level of lysine $(7.44 \%$ vs. $3.48 \%)$ and histidine $(1.50 \%$ vs. $0.66 \%$ ). On the other hand, the GL protein had a higher level of aspartic acid (8.48\% vs. $4.47 \%$ ), leucin $(7.09 \%$ vs. $4.90 \%)$ and phenylalanine (3.38\% vs. $1.48 \%)$.

\section{Carbohydrate composition}

The analysis of the neutral sugars was carried out using descending chromatography on paper of the products formed after acid hydrolysis on the AK and GL proteins, compared to controls. After the carbohydrates were quantified, the results were expressed in ug per mg of protein.

It was noted that the AK protein presented a higher level of galactose than the GL protein (28.8 vs. $4.6 \mathrm{ug} / \mathrm{mg}$ of protein) and a lower level of sialic acid $(0.27$ vs. $4.8 \mathrm{ug} / \mathrm{mg}$ of protein). The oligosacharides found were of the "N-linked" type. The presence of "O-linked" oligosacharides was not observed. The AK protein presented a greater total level of sugar residues than the GL protein ( $37.8 \mathrm{vs.} 12.6 \mathrm{ug} / \mathrm{ml}$ ). Based on this data it can be inferred that the ratio, expressed as a percentage of basic and neutral sugars, considered together in relation to the acids, was greater when compared to the GL protein (99.2:0 vs. $61.9: 38.1)$.

\section{Cytochemical Study of Protein Capture by the Cells}

\section{Light microscopy cytochemistry}

The detection of labelling, after endocytosis of the light chains by means of BHK cells, was assessed using semi-fine setions from pellets obtained from cells which had been fixed, dehydrated and included in LR White resin previously. The process of observation and photographic documentation was carried out using an Olympus (BH-2) microscope. The immunolabelling technique used in the protocol was carried out by means of the following sequence of reactions: use of antilight-chain protein A coupled to colloidal gold, followed by intensification using silver, thereby ensuring specificity in the reaction. The cells were efficient in the capture of the proteins after 5 minutes of incubation (Fig. 1), going towards the perinuclear region afterwards (Fig. 2). The intensity of non specific labelling was assessed in incubated cells using only the DMEM culture medium, without a light chain. In these cells which were used as a control, the degree of labelling was considered to be insignificant (Fig. 3). After 24 hours, it was noted that the GL protein tended to have perinuclear location (Fig. 4), whereas this trend was rarely observed in the $\mathrm{AK}$ protein after incubation (Fig. 5).

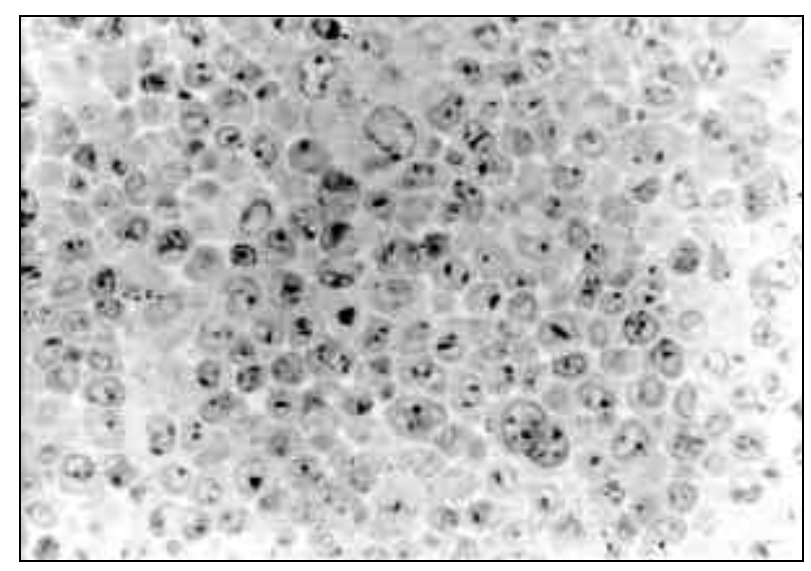

Figure 1 - Photo showing the capture of GL protein by BHK cells after 5 minutes of incubation (400x). 


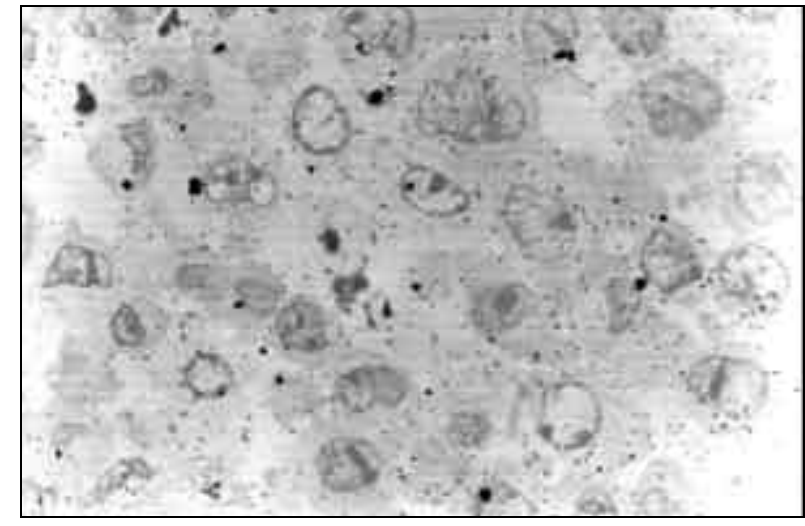

Figure 2 - Light chain immunolabelling after 24 hours incubation with GL protein (1000x).

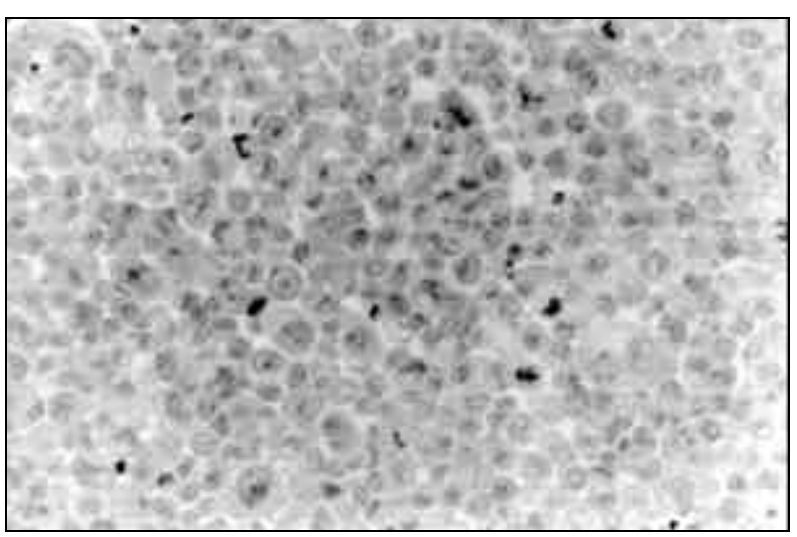

Figure 3 - Photo showing cells used as a control (400x).

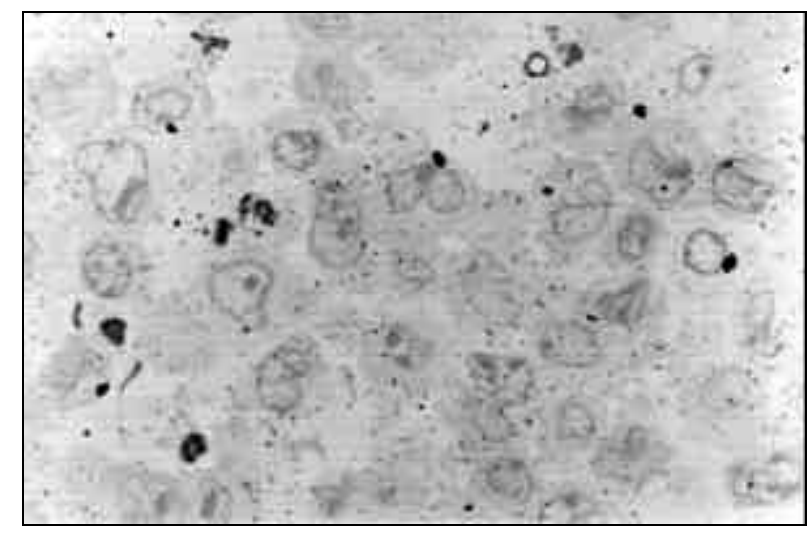

Figure 4 - Light chain immunolabelling in BHK cells after 24 hours incubation with GL protein (1000x).

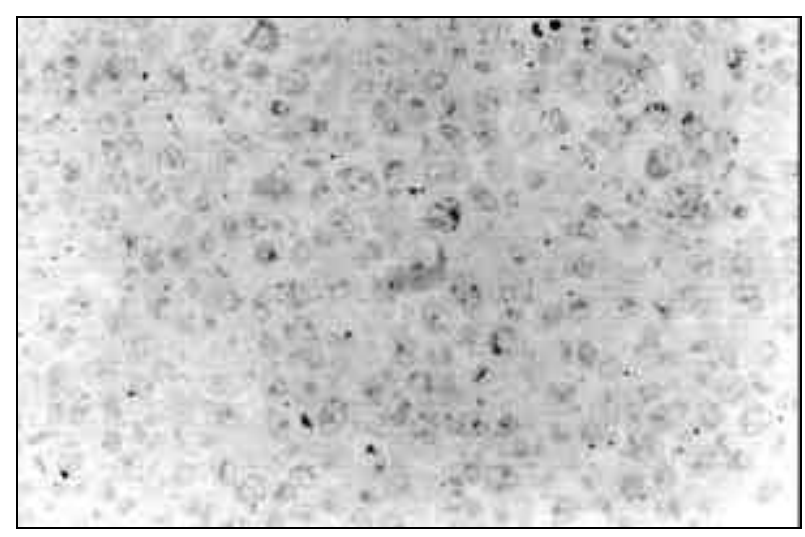

Figure 5 - Light chain immunolabelling in BHK cells after 24 hours incubation with AK protein (1000x).

\section{DISCUSSION}

It was observed that the two light chains, when isolated and purified, presented distinct physical and chemical differences, interfering with standard capture and intracellular movement, thus confirming studies made "in vivo", both in acute and also in chronic models (Prado et elii, 1993). The variability of the level of carbohydrates in the glycoproteins coincided with data found in published literature and interfered with distribution in the tissue, as has been demonstrated in scintillographic studies (Prado et alii, 1997). From the results obtained, there were signs that the AK protein tended to suffer lysosomal deviation as it was not found in the perinuclear region, unlike the GL protein, even after 24 hours of incubation.

A comparative study with the results obtained from other experimental models developed in our laboratory was set up. By assessing the differences existing between the "in vitro" handling of a light chain with an pI of 4.9 compared with an Ip of 7.4 in an entire animal, we observed that the capture of protein with a high Ip level is much more intense than that with a low Ip level. The study of the intracellular trajectory of the two proteins revealed that there was greater retention of the protein with a higher Ip, thus suggesting the occurrence of an alteration in the way it was processed. This data was obtained by means of electronic immunoelectromicroscopy, which enabled the quantification of the Bence-Jones proteins in components of the endosomallysosomal system (Nicastri et alii, 1998). Studies were carried out on various models: culture of epithelial renal cells, chronic infusion of a light chain, acute infusion in experimental animals and 
analysis of successive biopsies by means of the use of immuno-electromicroscopy techniques, using protein A coupled to colloidal gold (Nicastri, 1993). The intracellular trajectory of the different light chains was accompanied and distinct patterns of intracellular localisation were observed.

\section{CONCLUSIONS}

The BHK cells were effective in the internalisation of both light chains.

Immunolabelling was assessed through the entire incubation process.

The AK protein tended to suffer perinuclear deviation, not having a typical pattern of lysosomal localisation, thereby being different from the GL protein.

\section{RESUMO}

O objetivo deste trabalho foi avaliar a endocitose de duas proteínas de Bence Jones por células renais, com a finalidade de elucidar a interferência de características físico-químicas na nefrotoxicidade. As proteínas de Bence Jones (denominadas AK e GL) forma purificadas e isoladas da urina de dois pacientes com mieloma múltiplo. Isótopos de ambas as proteínas foram caracterizdos como sendo cadeias leves lambda monoclonais humanas. $\mathrm{AK}$ apresentou principalmente $\mathrm{pI}>7,0$, alto conteúdo de galactose e baixo teor de moléculas de ácido siálico. Por outro lado, GL apresentou uma única banda com pI 4,3, maior teor de ácido siálico e baixo teor de galactose, em comparação com AK. Células renais de hamster, BHK (Baby Hamster Kidney) foram mantidas em cultura à temperatura de $37^{\circ} \mathrm{C}$, utilizando meio de cultura DMEM suplementado com $10 \%$ de soro fetal bovino, em pH 7,4. Quando confluentes, as céluals BHK foram incubadas com as duas proteínas dissolvidas em meio isento de soro, durante $1,5,15,30,60$ minutos e 24 horas. Foi omitida a incubação com proteínas de Bence Jones em células usadas como controle. Com o término da incubação, as células foram lavadas, tripsinizadas, centrifugadas e fixadas em solução de paraformaldeído $4,0 \%$ e glutaraldeído $0,5 \%$ em

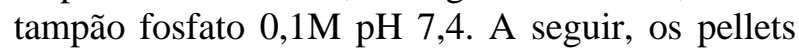
obtidos foram processados para microscopia e incluídos em LRWhite. Cortes semi-finos foram colhidos e submetidos a reações imunocitoquímicas, utilizando proteína Aacoplada a ouro coloidal e intensificação pela prata. A detecção da marcação foi avaliada em microscopia de luz. Os resultados mostraram que a proteína GL tendeu a ser direcionada para localização peri-nuclear. Por outro lado, AK demonstrou um comportamento diferente. Os dados indicaram que houve uma contribuição direta das características físico-químicas das proteínas no direcionamento intracelular.

\section{REFERENCES}

Cohn, D. J.; Sherman, W. H.; Osserman, E. F. and Appel, G. B. (1984), Acute renal failure in patients with multiple myeloma. Am. J. Med. 76, 247-256

Cooper, E. H.; Forbes, M. A.; Crockson, R. A. and Maclennan, I.C.M. (1984), Proximal renal tubular function in myelomatosis: observation in the fourth Medical Research Council trial. J. Clin. Pathol. 37, 852-858

Dwek, R. A.; Edge, C. J.; Harvey, D. J. and Wormald, M. R. (1993), Analysis of glycoprotein-associated oligisaccharides .Annu. Rev. Biochem. 62, 65-100

Endo, T. and Kobata, A. (1989), Structure and function of tha carbohydrate chains on immunoglobulin $G$ Mod. Media., 32, 423-33

Endo, T. and Kobata, A. (1989), Structure and function of the carbohydrate chains on immunoglobulin G. Mod. Media. 32, 423-433

Harada, H.; Kamei, M.; Tokumoto, Y.; Yui, S.; Koyama, F.; Kochibe, N.; Endo, T. and Kobata, A. (1987), Systemic fractionation of oligosaccharides of human IgG by serial affinity chromatografy on immobilized lectin columns. Anal. Biochem. 164, 374-381

Jansen, R. W.; Molema, G.; Ching, T. L.; Oosting, R.; Harms, G.; Moolenaar, F.; Hardonk, M.J. and Meijer, D. K. F. (1991), Hepatic endocytosis of various types of mannose-terminated albumins. J.Biol. Chem. 266 (5), 3343-3348

Jonhson, I. and Clamp Jr. (1971), The oligosaccharide units of a human type $\mathrm{L}$ immunoglobulin $\mathrm{M}$ (macroglobulin). Biochem. J. 123, 739-745

Kyle, R. (1983 ), Long term survival in multiple myeloma, New Engl J Med. 10, 314-316

Laemmli, U. K. (1970), Cleavage of structural proteins during the assembly of the head of bacteriophage T4. Nature 227, 680-685

Melcion, C.; Mougenot, B.; Baldouin, B.; Ronco, P.; Moulonguet-Doleris, L.; Vanhille, P.H.; Beaufils, M.; Morel-Maroger, L.; Verroust, P. and Richet, G. (1984), Renal failure in multiple myeloma: relashionship with isoeletric point of imunoglobulin light chains “. Clin. Nephrol. 22(3), 138-143 
Mizuochi, T.; Taniguchi, T.; Shimizu, A. and Kobata, A. (1982), Structural and numerical variations of the carbohydrate moiety of immunoglobulin G. $J$. Immunol.129, 2016-2020

Nicastri, A.L. (1993), Influência de características físico-químicas na captação e processamento intracelular de proteins de Bence Jones humanas em células epiteliais renais. Tese apresentada ao Instituto de Ciências Biomédicas da Universidade de São Paulo para obtenção do título de Doutor em Fisiologia

Nicastri, A. L.; Prado, M. J. B. A.; Sesso, A. and Prado, E. B. A. (1998), Defective proximal tubule lysosomal acidification by Bence Jones protein. Experimental Nephrology: 6, 517-521

Ohkura, T.; Isobe, T.; Yamashita, K. and Kobata, A. (1985), Structures of the carbohydrate moieties of two monoclonal human $\lambda$-type immunoglobulin light chains. Biochemistry 24, 503-508

Prado, E. B. A.; Prado, M. J. B. A. and Nicastri, A. L. (1993), Nefropatia associada a paraproteínas. Atualidades em Nefrologia II. Cruz, J.; David Neto, E.; Magalhães, R.L. ; Alves, M.A.U.F.R.; Serpa, R.G.; Salgado Filho, N.; Praxedes, J.N.; Editora Sarvier, SP, 71-78

Prado, M. J. B. A.; Nicastri, A.L.; Costa Rockman, T.; Tersariol, J. L. S.; Nader, M. B.; Barros, R. T.; Prado, E. B. A. (1997), The renal and hepatic distribution of Bence Jones proteins dependes on glycosylation: a scintigraphic study in rats. Brazilian Journal of Medical and Biological Research 30, 865872

Prado, M. J. B. A; Nicastri, A. L.; Leo, P.; Uchhio, E.; Sesso, A.; Marcoondes, M.; Prado, E. B. A. (1993), Nephrotoxicity oh human Bence Jones protein in rats: proteinuria and Enzymnuria profile. Braz. J. Med. Biol. Res. 26, 633-638

Putnam, F. W.; Florent, G.; Paul, C.; Shinoda, T. and Shimizu, A. (1973 ), Complete amino acid sequence of the mu heavy chain of a human IgM immunoglobulin. Science 182, 287-291

Radola, B.J. (1980), Ultrathin-layer isoeletric focusing in 500-100 um polycrylamide gels on silanized glass plates or polyester films. Electrophoresis 1, 34-56
Sanders, P. W.; Herrera, G. A.; Lott, R. L. and Galla, J.H. (1988), Morphologic alterations of the proximal tubules in light chain-related renal disease ". Kidney Int. 33, 881-889

Silver, M. M.; Hearn, S. A.; Ritchie, S.; Slinger, R. P.; Sholdice, J. A.; Cordy, P. S. and Hodsmann, A. B. (1986), Renal and systemic Kappa light deposits and their plasma cell origin identified by immunoelectron microscopy". Am. J. Pathol.122, 17-27

Sinclair, D.; Dagg, J. H.; Smith, J. G. and Stott, D.I. (1986), The incidence and possible relevance of Bence Jones protein in the sera of patients with multiple myeloma. British J. Hemat. 62, 689-694

Solomon, A.; Weiss, D. T. and Kattine, A. (1991), Nephrotoxic potencial of Bence Jones proteins. The New England Journal of Medicine 324(26), 18451851

Sox Jr., H. C. and Hood, L. (1970), Attachment of carboydrate to the variable region of myeloma immunoglobulin light chains. Proc. Natl. Acad. Sci. U.S.A. 66, 975-982

Spiro, R. G. (1966), Analysis of sugars found in glycoproteins. Methods Enzymol. 8, 3-52

Svennerholm, L. (1957), Quantitative estimation of sialic acids - II. A colorimetric resorcinolhydrochloric acid method. Biochim. Biophys. Acta 24, 604-611

Takasaki, S.; Mizuoki, T. and Kobata, A. (1982), Hydrazinolysis of asparagine-liked sugar chains to produce free oligosaccharides. Methods Enzymol. 83, 263-268

Trevelyan, W. E.; Procter, D. P. and Harrison, J. S. (1950), Detection of sugar on paper chromatograms. Nature. 166, 444

Weiss, J. H.; Willians, R. H; Galla, J. H.; Gottschall, J. L.; Rees, E. D.; Bathena, D. and Luke, R. G. (1981), Pathophysiology of acute Bence Jones protein nephrotoxicity in the rat “. Kidney Int. 20(2), 198-210

Received: June 10, 1999;

Revised: June 18, 1999; Accepted: August 25, 2000. 